\title{
Water Quality Analysis based on Remote Sensing Data and Numerical Model
}

\author{
Yoichi KAGEYAMA* and Makoto NISHIDA*
}

\begin{abstract}
To analyze the relationship between temporary changes in water current and water pollution, we constructed a numerical model for drift current in this paper. Water quality estimation maps were also drawn by fuzzy regression analysis between remote sensing data and water quality measurements. Lake Hachiro in Akita was selected as the test site for the case study. Computer simulation result of the flow vector agreed well with the water quality estimation maps. It can be concluded that drift current helps clarify water quality.
\end{abstract}

Key words : water quality, drift current, water quality estimation map, remote sensing data

\section{Introduction}

Water pollution in lakes, marshes, and rivers is increasing, making the monitoring of water quality particularly important. Water quality is usually studied by collecting water directly at measurement sites. A direct survey of wide areas such as lakes is neither practical nor economical. A synoptic view from remote sensing data is useful in understanding water quality (Tanaka et al., 1990). Therefore, water quality was analyzed using remote sensing data (Inomata and Ogata, 1990; Miyazaki et al., 1991; Oki and Yasuoka, 1997). Clouds may adversely influence optical sensors such as the Landsat Thematic Mapper (TM), and remote sensing data shows only temporary water quality. To observe water quality continuously, water movement in lakes should be considered in addition to remote sensing data. We studied the relationship between water quality estimation maps by fuzzy regression analysis and the drift current computed by a numerical model for Lake Hachiro, Akita.

\section{Test Site and Data Acquisition}

Lake Hachiro in Akita, Japan, was selected as the test site. The lake is located in northwest of Akita-city. Ogata village was reclaimed land extending $18-\mathrm{km}$ from north to south and $12-\mathrm{km}$ from east to west. Figure 1 shows the outline of Lake Hachiro and the measurement sites of water quality. Seven measurement sites (St. 1 to St. 7) are used.

Seven water quality parameters were measured on June 8, 1994 at seven sites (Table 1). They were hydrogen-ion indicator $(\mathrm{pH})$, dissolved oxygen (DO), biochemical oxygen demand (BOD), chemical oxygen demand (COD), suspended solids (SS), total nitrogen (T-N), and total phosphorus (T-P).

Landsat TM data on June 16, 1994 was analyzed; twenty-five pixels around each

* Computer Science \& Engineering, Faculty of Engineering and Resource Science, Akita University.

* 1-1 Tegata Gakuen-machi, Akita-city, Akita 010-8502, Japan. 


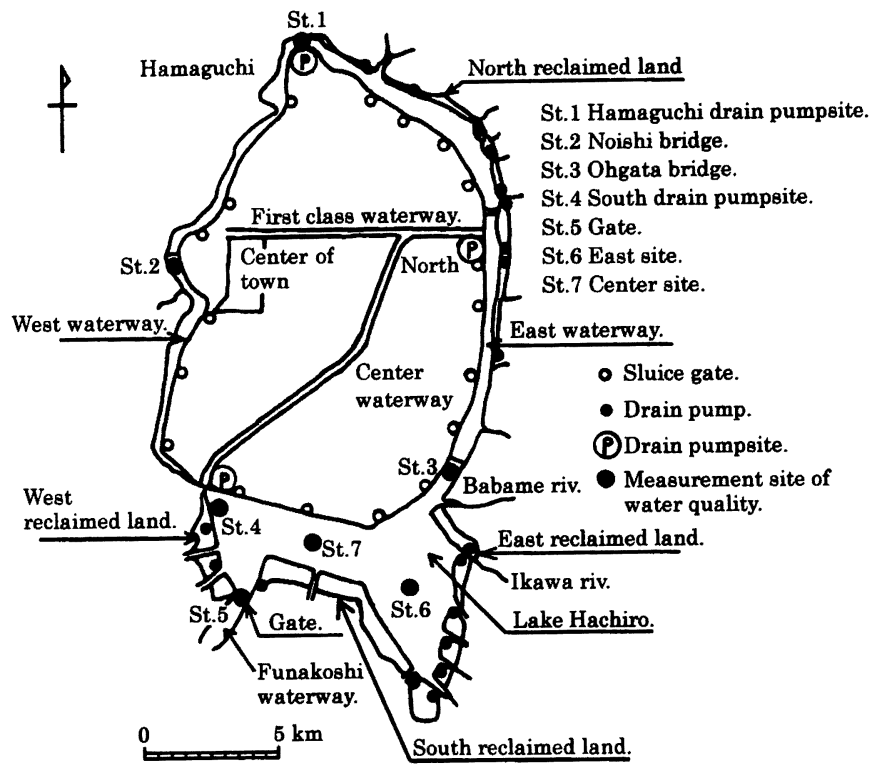

Fig. 1 Outline of Lake Hachiro and the measurement sites of water quality.

Lake Hachiro is located in northwest of Akita-city, Japan. There are seven measurement sites of water quality for analysis (St. 1 to St. 7).

Table 1 Measurements of water quality.

\begin{tabular}{l|c|c|c|c|c|c|c}
\hline \multirow{2}{*}{ Measurement site of water quality } & \multicolumn{7}{|c}{ Water quality } \\
\cline { 3 - 8 } & PH & DO & BOD & COD & SS & T-N & T-P \\
\hline 1. Hamaguchi drain pumpsite & 7.4 & 9.2 & 3.2 & 3.5 & 14 & 0.90 & 0.06 \\
2. Noishi bridge & 8.3 & 10.0 & 12.0 & 6.7 & 34 & 1.10 & 0.10 \\
3. Ogata bridge & 7.7 & 9.5 & 3.4 & 2.8 & 6 & 0.63 & 0.05 \\
4. South drain pumpsite & 7.8 & 9.3 & 6.0 & 1.7 & 16 & 0.36 & 0.05 \\
5. Gate & 7.8 & 9.6 & 7.5 & 2.5 & 15 & 0.53 & 0.11 \\
6. East site & 7.8 & 9.1 & 5.0 & 2.2 & 13 & 0.34 & 0.04 \\
7. Center site & 7.8 & 9.3 & 5.7 & 1.7 & 25 & 0.39 & 0.07 \\
\hline
\end{tabular}

pH: hydrogen-ion indicator. DO: dissolved oxygen, BOD: biochemical oxygen demand, COD: chemical oxygen demand, SS: suspended solids, T-N: total nitrogen, T-P: total phosphorus. -Dimension of water quality: $m g / l$ (except PH)

measurement site were obtained by the operator. Table 2 shows the average and standard deviation of TM CCT count number (luminous intensity) at measurement sites; sixth-band TM data was excluded due to its different resolution. Data acquisition for water quality differed from Landsat TM data. Although 2-mm of rainfall occurred on June 14, 1994, at Ogata village, it was considered that the influence of the rainfall on water quality trends is very little.

Weather data for the day on which TM data was taken was used for computer simulation. The wind velocity and direction 
Table 2 Average and Standard deviation of the CCT count number of TM-band at measurement sites.

\begin{tabular}{|c|c|c|c|c|c|c|}
\hline \multirow{2}{*}{$\begin{array}{l}\text { Measurement site of water } \\
\text { quality }\end{array}$} & \multicolumn{6}{|c|}{ Landsat TM data } \\
\hline & Band 1 & Band 2 & Band 3 & Band 4 & Band 5 & Band 7 \\
\hline 1. Hamaguchi drain pumpsite & $\begin{array}{l}75.680 \\
(1.287)\end{array}$ & $\begin{array}{l}26.600 \\
(0.894)\end{array}$ & $\begin{array}{l}23.640 \\
(0.557)\end{array}$ & $\begin{array}{l}13.200 \\
(0.490)\end{array}$ & $\begin{array}{c}5.440 \\
(0.852)\end{array}$ & $\begin{array}{c}1.880 \\
(0.711)\end{array}$ \\
\hline 2. Noishi bridge & $\begin{array}{l}78.880 \\
(1.211)\end{array}$ & $\begin{array}{l}28.040 \\
(0.720)\end{array}$ & $\begin{array}{l}27.240 \\
(1.242)\end{array}$ & $\begin{array}{l}14.840 \\
(2.344)\end{array}$ & $\begin{array}{c}9.440 \\
(1.920)\end{array}$ & $\begin{array}{c}3.000 \\
(1.166)\end{array}$ \\
\hline 3. Ogata bridge & $\begin{array}{l}74.400 \\
(1.265)\end{array}$ & $\begin{array}{l}24.320 \\
(0.614)\end{array}$ & $\begin{array}{l}20.560 \\
(0.753)\end{array}$ & $\begin{array}{l}11.080 \\
(0.560)\end{array}$ & $\begin{array}{c}5.320 \\
(1.256)\end{array}$ & $\begin{array}{c}1.400 \\
(0.693)\end{array}$ \\
\hline 4. South drain pumpsite & $\begin{array}{l}81.560 \\
(1.472)\end{array}$ & $\begin{array}{l}31.040 \\
(0.528)\end{array}$ & $\begin{array}{l}28.880 \\
(0.711)\end{array}$ & $\begin{array}{l}12.000 \\
(0.490)\end{array}$ & $\begin{array}{c}4.840 \\
(0.880)\end{array}$ & $\begin{array}{c}1.720 \\
(1.950)\end{array}$ \\
\hline 5. Gate & $\begin{array}{l}77.320 \\
(1.009)\end{array}$ & $\begin{array}{l}27.840 \\
(0.543)\end{array}$ & $\begin{array}{l}24.960 \\
(0.599)\end{array}$ & $\begin{array}{l}11.920 \\
(1.197)\end{array}$ & $\begin{array}{c}5.760 \\
(1.209)\end{array}$ & $\begin{array}{c}1.880 \\
(1.681)\end{array}$ \\
\hline 6. East site & $\begin{array}{l}78.120 \\
(1.107)\end{array}$ & $\begin{array}{l}28.840 \\
(0.463)\end{array}$ & $\begin{array}{l}24.240 \\
(0.512)\end{array}$ & $\begin{array}{l}11.360 \\
(0.625)\end{array}$ & $\begin{array}{c}5.000 \\
(0.980)\end{array}$ & $\begin{array}{c}0.880 \\
(0.711)\end{array}$ \\
\hline 7. Center site & $\begin{array}{l}81.120 \\
(0.993)\end{array}$ & $\begin{array}{l}30.880 \\
(0.816)\end{array}$ & $\begin{array}{l}27.840 \\
(1.376)\end{array}$ & $\begin{array}{l}11.680 \\
(0.546)\end{array}$ & $\begin{array}{c}5.120 \\
(0.816)\end{array}$ & $\begin{array}{c}1.360 \\
(1.015)\end{array}$ \\
\hline
\end{tabular}

( ): Standard deviation.

Landsat TM data taken on June 16, 1994 was used in this paper. Twenty-five pixels around the measurement site for water quality were obtained by the operator.

registered $1.7 \mathrm{~m} / \mathrm{s}$ NNW on June 16, 1994 .

\section{Data Analysis}

\section{1) Fuzzy regression model}

The fuzzy regression model assumes that the difference between observation data and the model indicates system fuzziness, showing the relationship of input and output (Ishibuchi, 1992). Remote sensing data includes external disturbance components, e.g., path radiance, sun glitter, atmosphere scattering and absorption, water surface waves, and sensing system noise (Yokoyama, 1983). It is necessary to consider fuzziness in data processing. It is difficult to specify measurement sites in images because the resolution ability of LANDSAT TM is $30-\mathrm{m}$. Given these restrictions, the CCT count number distribution includes fuzziness. We assume that the distribution of the CCT count number is a fuzzy number.

In this paper, fuzzy regression analysis was conducted using both remote sensing data and measurements of water quality parameters. The fuzzy regression model was computed using the following equation (Nishida et al., 1995):

$$
\begin{aligned}
Y\left(X_{p}\right) & =A_{0}+A_{1} X_{p 1}+\cdots+A_{n} X_{p n} \\
& =\left(a\left(X_{p}\right), e\left(X_{p}\right)\right)_{L}
\end{aligned}
$$

where

$$
\begin{aligned}
& a\left(X_{p}\right)=a_{0}+a_{1} X_{p 1}+\cdots+a_{n} X_{p n} \\
& e\left(X_{p}\right)=e_{0}+e_{1}\left|X_{p 1}\right|+\cdots+e_{n}\left|X_{p n}\right|
\end{aligned}
$$

$A_{i}$ is a fuzzy coefficient, $Y\left(X_{p}\right)$ is an estimate (fuzzy number), $a\left(X_{p}\right)$ is the center (mean) of $Y\left(X_{p}\right)$, and $e\left(X_{p}\right)$ is the width of $Y\left(X_{p}\right)$. Equation (2) is the fuzzy regression model with the center and width of the fuzzy number. Since the fuzzy regression model is the one-input and one-output, four variables $\left(a_{0}, e_{0}, a_{1}, e_{1}\right)$ are obtained by the following equations:

$$
\begin{aligned}
& Y\left(X_{p}\right)=A_{0}+A_{1} X_{p} \\
& =\left(a_{0}, e_{0}\right)_{L}+\left(a_{1}, e_{1}\right)_{L} X_{p}
\end{aligned}
$$

where $X_{p}$ is the measurements of water quality, $A_{1}$ the triangular fuzzy number, $a_{1}$ the center of the fuzzy number, $e_{1}$ the width 


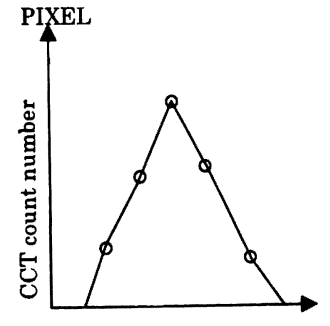

(a) Measurement value

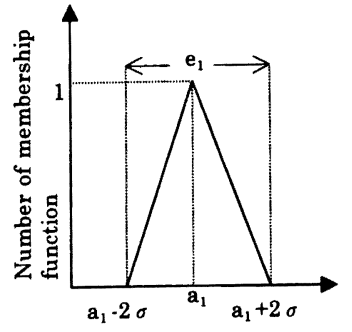

(b) Triangular fuzzy number
Fig. 2 Measurement value and triangular fuzzy number of the CCT count number.

The triangular fuzzy number was produced by a vertex $\left(a_{1}\right)$ and the width $\left(e_{1}\right)$, which was twice the standard deviation $(\sigma)$.

of the fuzzy number, and $Y\left(X_{p}\right)$ the estimation fuzzy output interval. The mean CCT count number and the triangular fuzzy number were used for analysis. The triangular fuzzy number was produced by a vertex $\left(a_{1}\right)$ and the width $\left(e_{1}\right)$, which was twice the standard deviation $(\sigma)$ is shown in Fig. 2.

\section{2) Fuzzy level-slice processing}

The fuzzy output interval obtained by the fuzzy regression model shows that the CCT count number corresponds to the forecasted range obtained by measuring water quality parameters. It has already clarified that water quality estimation maps by using fuzzy level-slice processing can show the intermediate levels of water quality in comparison with conventional level-slice processing (Nishida and Otsuka, 1995). In order to understand water quality in detail, the estimation maps in this paper were drawn by means of fuzzy level-slice processing. The technique employs simplification fuzzy reasoning (Mizumoto, 1992).

We assume that the CTT count number shows the possibility of corresponding to the specific level of water pollution that set in optional range. The production rule for estimating water quality in the pixel is as follows:

$$
\begin{aligned}
& \text { Rule 1: } Y_{1} \rightarrow Z_{1} \\
& \cdot \cdot \cdot \cdot \cdot \cdot \\
& \text { Rule } \mathrm{n}: Y_{\mathrm{n}} \rightarrow Z_{\mathrm{n}} \\
& \text { Input: } S \\
& \hline \text { Output: }
\end{aligned}
$$

where $Y_{\mathrm{i}}(i=1, \ldots, \mathrm{n})$ is an estimation fuzzy set of the CTT count number in proportion to the slice level, and $\mathrm{Z}_{i}(i=1, \ldots, \mathrm{n})$ is water quality in each rule. $S$ is the input of the CCT count number. $Z_{0}$ is the output. Output $Z_{0}$ is given by

$$
Z_{0}=\frac{\sum_{i=1}^{n} h_{i} Z_{i}}{\sum_{i=1}^{n} h_{i}}
$$

When input $S$ is given, $h_{i}$ is the ratio for getting the $Z_{i}$. Rule number corresponds to the slice number. The slice number was six in this paper.

\section{3) Numerical model}

A stream is the flow of water, caused by factors such as wind, water inflow and outflow, heat, attraction (gravity), and atmospheric pressure. These factors influence each other and flows are created by control factors, e.g., Coriolis force caused by the form of lakes, water surface, water depth, and global rotation.

Water quality distribution shows the concentration of chemicals, e.g., suspended solids and total nitrogen. The water current gives rise to mixing and diffusion of water quality. It is reported that wind causes the water current in lakes (Tanaka et al., 1990). Therefore, numerical simulation was conducted to analyze the relationship between water current and quality. The numerical model for the drift current was constructed using a finite element method. The flow numerical analysis 
model in dimension 2 accounts for the following assumptions (Tanaka et al., 1990; Onishi et al., 1986):

(1) The vertical change in water is minimal because all of Lake Hachiro is shallow.

(2) Water density is constant.

(3) Pressure distribution is steady.

(4) Atmospheric pressure is almost constant. The drift current is expressed as follows:

$$
\begin{aligned}
& \frac{\partial M}{\partial t}=f N-g(h+\zeta) \frac{\partial \zeta}{\partial x}+\frac{1}{\rho_{w}}\left(\tau_{x}(s)-\tau_{x}(b)\right) \\
& \frac{\partial N}{\partial t}=f M-g(h+\zeta) \frac{\partial \zeta}{\partial y}+\frac{1}{\rho_{w}}\left(\tau_{y}(s)-\tau_{y}(b)\right) \\
& \frac{\partial \zeta}{\partial t}+\frac{\partial M}{\partial x}+\frac{\partial N}{\partial y}=0
\end{aligned}
$$

where

$M$ is the flux in direction $\mathrm{x}$ and $N$ that in direction $\mathrm{y}: M=(h+\zeta) U, N=(h+\zeta) V$.

$U$ is the mean flow velocity in direction $\mathrm{x}$ and $V$ that in direction $y$.

$f$ is the Coriolis force: $\mathrm{f}=2 \omega \sin \phi$.

$\omega$ is the angular velocity of global rotation. $\phi$ is latitude.

$\zeta$ is the height between data plane and water surface.

$h$ is the water depth between data plane and

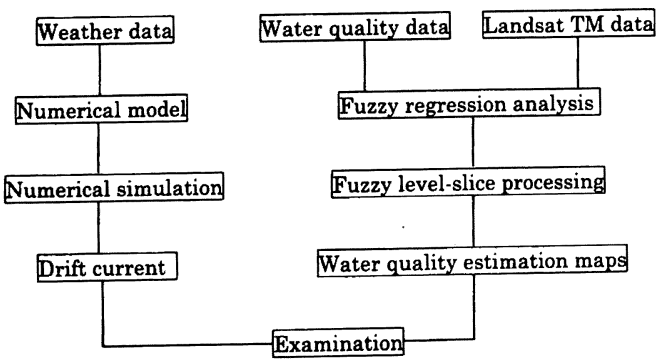

Fig. 3 Flowchart for data analysis.

This paper investigates the relationship between the water quality estimation map using Landsat TM data and measurements of water quality, and the drift current computed by a numerical model. bottom.

$\tau_{x}(b), \tau_{y}(b)$ is the shear at the bottom in directions $\mathrm{x}$ and $\mathrm{y}$.

$\tau_{x}(s), \tau_{y}(s)$ is the shear on the water surface in directions $\mathrm{x}$ and $\mathrm{y}$.

Shear is obtained by the following equation.

$\tau_{x \text { or } y}(b)=\rho_{w} \gamma_{b}^{2} U_{\text {or }} V \sqrt{U^{2}+V^{2}}-\beta \tau_{x \text { or } y}(s)$

$\tau_{x \text { or } y}(s)=\rho_{a} \gamma_{a}^{2} W_{x \text { or } y} \sqrt{W_{x}^{2}+W_{y}^{2}}$

$\rho_{a}$ is atmospheric density.

$\rho_{w}$ is water density.

$\gamma_{a}^{2}=1.3 \times 10^{-3}$.

$\gamma_{b}^{2}=2.6 \times 10^{-3}$.

$\beta=1.0$.

$W_{x}, W_{y}$ is the wind velocity in directions $\mathrm{x}$ and $y$. Computer simulations for the drift current were conducted under the initial condition that $M=0, N=0, \zeta=0$.

Figure 3 shows the flowchart for data analysis in this paper.

\section{Results and Discussion}

\section{1) Fuzzy regression analysis result}

Since the fuzzy regression model analyzes a one-input and one-output system, four variables $\left(a_{0}, e_{0}, a_{1}, e_{1}\right)$ must be obtained. When the complete solution or the objective function was not determined, the complete fuzzy regression analysis result was not obtained. Table 3 shows the result of fuzzy regression analysis with average number. The solution of ten sets was obtained. When the fuzzy number of remote sensing data is used for analysis, it is also necessary to solve min and max problems (Ishibuchi, 1992). The complete result (four variables) for the $\mathrm{min}$ problem is shown in Table 4 (eleven sets) and the complete result for the max problem (seven sets) in Table 5 . In water quality parameters, DO is not related to the CCT count number of TM data. Two combinations- 
Table 3 Result of fuzzy regression analysis with average number.

\begin{tabular}{c|c|c|c|r|r|r|r}
\hline No & TM Band & Water quality parameter & Objective Function & \multicolumn{1}{c|}{$\boldsymbol{a}_{0}$} & \multicolumn{1}{c|}{$\boldsymbol{a}_{1}$} & $\boldsymbol{e}_{0}$ & $\boldsymbol{e}_{1}$ \\
\hline 1 & 1 & $\mathrm{pH}$ & 22.447 & 16.907 & 7.878 & 0 & 0.411 \\
2 & 4 & $\mathrm{SS}$ & 7.166 & 11.471 & 0.057 & 0.581 & 0.025 \\
3 & 4 & $\mathrm{~T}-\mathrm{N}$ & 6.598 & 10.618 & 2.285 & 0 & 1.553 \\
4 & 4 & $\mathrm{~T}-\mathrm{P}$ & 7.740 & 10.560 & 27.500 & 0.180 & 13.500 \\
5 & 5 & BOD & 3.723 & 3.651 & 0.688 & 0 & 0.176 \\
6 & 5 & SS & 7.468 & 4.390 & 0.089 & 0.047 & 0.058 \\
7 & 5 & T-N & 6.689 & 3.014 & 4.269 & 0 & 1.573 \\
8 & 5 & T-P & 9.216 & 4.000 & 35.200 & 0 & 19.200 \\
9 & 7 & SS & 3.560 & 0.728 & 0.048 & 0.368 & 0.008 \\
10 & 7 & T.P & 3.175 & 0.374 & 19.943 & 0.006 & 5.657 \\
\hline
\end{tabular}

Ten sets of the results are obtained with average number.

Table 4 Result of fuzzy regression analysis with fuzzy number (Min problem).

\begin{tabular}{r|c|c|c|r|r|r|r}
\hline No & TM Band & Water quality parameter & Objective Function & \multicolumn{1}{c|}{$a_{0}$} & \multicolumn{1}{|c|}{$a_{1}$} & $e_{n}$ & $e_{1}$ \\
\hline 11 & 1 & pH & 41.543 & 12.991 & 8.408 & 0 & 0.761 \\
12 & 4 & COD & 21.974 & 11.278 & 0.251 & 0.958 & 0.357 \\
13 & 4 & BOD & 18.724 & 10.182 & 0.695 & 1.029 & 0.546 \\
14 & 4 & SS & 19.662 & 9.831 & 0.147 & 0.799 & 0.114 \\
15 & 4 & T-N & 19.447 & 9.369 & 4.973 & 0.425 & 3.875 \\
16 & 4 & T-P & 23.831 & 10.322 & 42.415 & 0 & 49.648 \\
17 & 5 & COD & 22.580 & 3.855 & 0.404 & 1.823 & 0.229 \\
18 & 5 & BOD & 20.445 & 2.972 & 0.965 & 2.169 & 0.249 \\
19 & 5 & SS & 24.263 & 4.510 & 0.120 & 2.155 & 0.075 \\
20 & 5 & T-N & 22.243 & 3.722 & 3.758 & 0.410 & 4.558 \\
21 & 5 & T-P & 24.487 & 2.555 & 57.117 & 0.192 & 48.217 \\
\hline
\end{tabular}

Eleven sets of the results are obtained by solving the Min problem.

Table 5 Result of fuzzy regression analysis with fuzzy number (Min problem).

\begin{tabular}{r|c|c|c|r|r|r|r|r}
\hline No & TM Band & Water quality parameter & Objective Function & \multicolumn{1}{c|}{$\boldsymbol{a}_{n}$} & \multicolumn{1}{c|}{$\boldsymbol{a}_{1}$} & $\boldsymbol{e}_{0}$ & $\boldsymbol{e}_{1}$ \\
\hline 22 & 4 & BOD & -1.683 & 9.887 & 0.746 & 0 & 0.080 \\
23 & 4 & SS & -0.970 & 12.019 & 0.022 & 0 & 0.008 \\
24 & 4 & T.P & -1.064 & 10.770 & 26.383 & 0 & 2.217 \\
25 & 5 & COD & -8.100 & 3.058 & 0.401 & 0 & 0.189 \\
26 & 7 & COD & -7.708 & 0.382 & 0.204 & 0 & 0.180 \\
27 & 7 & SS & -7.773 & 0.717 & 0.051 & 0.406 & 0.040 \\
28 & 7 & T.P & -9.923 & 0.497 & 20.758 & 0.354 & 15.508 \\
\hline
\end{tabular}

Seven sets of the results are obtained by solving the Max problem. 
Table 6 Correlation coefficient between water quality and the CCT count number of TM data.

\begin{tabular}{l|r|r|r|r|r|r}
\hline & Band 1 & Band 2 & Band 3 & Band 4 & Band 5 & Band 7 \\
\hline PH & 0.412 & 0.253 & 0.462 & 0.497 & 0.786 & 0.579 \\
DO & -0.050 & -0.229 & 0.125 & 0.638 & 0.882 & 0.847 \\
BOD & 0.399 & 0.274 & 0.550 & 0.700 & 0.862 & 0.777 \\
COD & -0.204 & -0.329 & 0.012 & 0.894 & 0.958 & 0.858 \\
SS & 0.574 & 0.474 & 0.708 & 0.750 & 0.755 & 0.686 \\
T-N & -0.402 & -0.497 & -0.152 & 0.860 & 0.804 & 0.826 \\
T-P & 0.050 & -0.004 & 0.253 & 0.527 & 0.636 & 0.706 \\
\hline
\end{tabular}

The correlation coefficient between the pollution concentration of water quality and the CCT count number of first, second and third band is low. The resulting correlation coefficient on fourth. fifth and seventh band is high, especially for the correlation coefficient on the fifth band.

SS and fourth-band TM data, and T-N and fourth-band TM data-obtain the complete results even using the average or the fuzzy number (both $\min$ and $\max$ problems). In addition to fourth-band TM data, fifth-band TM data gets the fuzzy regression analysis result.

To compare measurements of water quality and the CCT count number of TM data, the correlation coefficient was computed (Table 6). The correlation coefficient between the pollution concentration of water quality and the CCT count number of first, second and third band is low. The resulting correlation coefficient on fourth, fifth and seventh band is high, especially for the correlation coefficient on the fifth band. These spectral bands of TM data are related to measurements of water quality in this paper.

\section{2) Comparison of results}

Landsat TM image at the test site is shown in Fig. 4. Points $\mathrm{A}, \mathrm{B}$, and $\mathrm{C}$ are regions set for the examination. Typical examples of water quality estimation map are shown in Figs. 5 -- SS and CCT count number of fifthband TM data -- and 6. -- T-N and CCT count number of fifth-band TM data. The pollution level of water quality in estimation maps from point $\mathrm{A}$ to point $\mathrm{C}$ is remarkably high, especially the resulting using $\mathrm{T}-\mathrm{N}$ and fifthband TM data (Fig. 6).

The distribution of the flow vector is shown in Fig. 7. The drift downwind current exists throughout the lake. An annulus flow also occurs around points A, B, and C. Little water circulation may occur at these points, indicating that little circulation may increase pollution at all points. The simulation result for the numerical model corresponds to the water pollution in the estimation maps. Although both water inflow and effluent influence water quality at influx and efflux, the stagnating flow pollutes water quality. That is to say, the entire Lake Hachiro is greatly influenced by drift current.

\section{Conclusion}

To analyze the relationship between temporary change of water current and the pollution of water quality, we constructed a numerical model for drift current. Water quality estimation maps were also drawn 


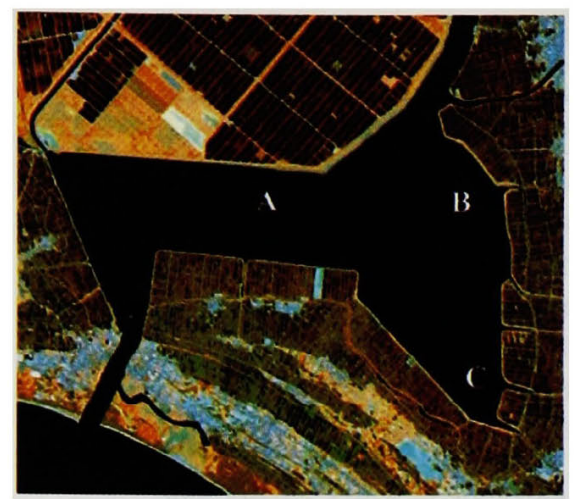

Fig. 4 Landsat TM image at the test $\operatorname{site}(R, G, B$ : Band 4,5,7). Landsat TM data was taken on June 16, 1994. Points A, B, and C are regions set for the examination.
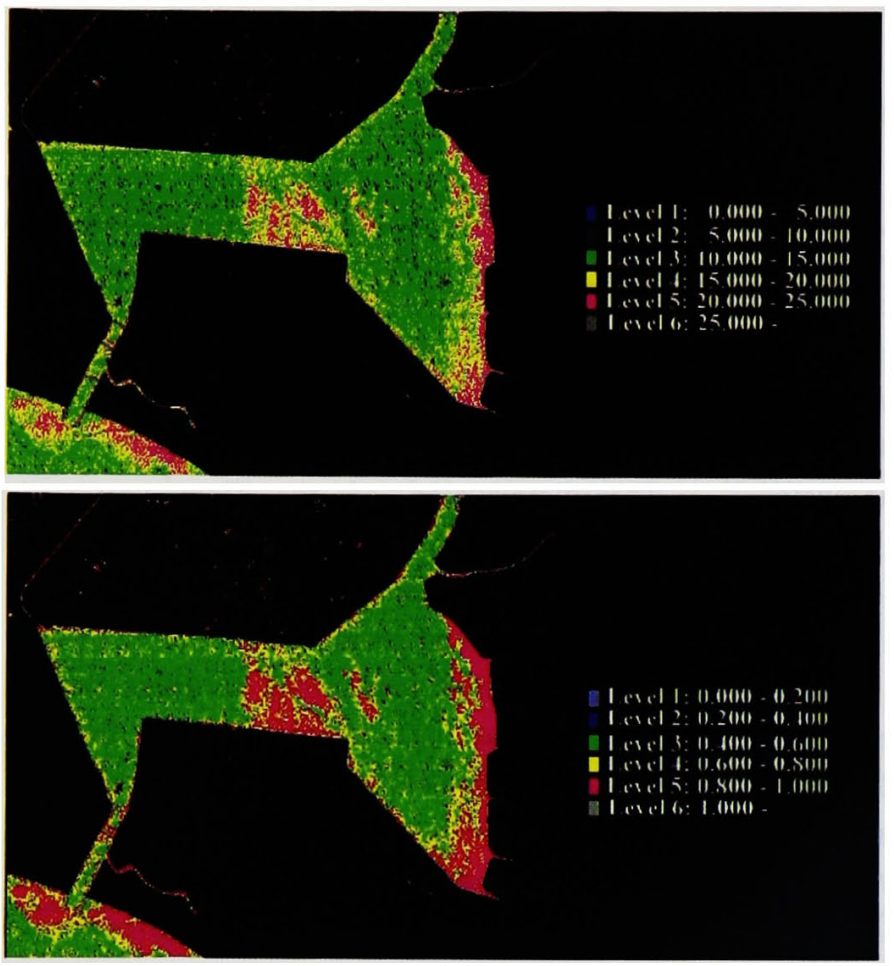

flow velocity $(\mathrm{m} / \mathrm{s})$

$$
\begin{aligned}
& \text { D } \sim 0.01 \\
& 0.01 \sim 0.02 \\
& 0.02 \sim 0.03 \\
& 0.03 \sim 0.04 \\
& 0.04 \sim 0.05 \\
& 0.05 \sim 0.1 \\
& 0.1 \sim 1
\end{aligned}
$$

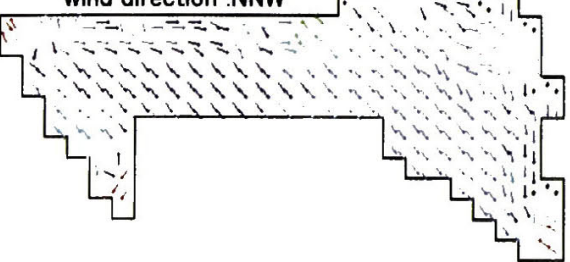

Fig. 5 Water quality estimation map for fuzzy level-slice processing. The estimation map is obtained using SS and the CCT count number of fifth-band TM data.

Fig. 6 Water quality estimation map for fuzzy level-slice processing. The estimation map is obtained using $\mathrm{T}-\mathrm{N}$ and the CCT count number of fifthband TM data. 
using fuzzy regression analysis between remote sensing data and measurements of water quality. Lake Hachiro in Akita was the test site for the case study. Computer simulation result of the flow vector agreed well with the water quality estimation maps. It can be concluded that drift current helps clarify water quality.

\section{Acknowledgments}

The authors wish to express their thanks to Ms. Chikako Ishizawa and Ms. Takako Sato for their experimental help. The authors also wish to express their thanks to Environment Preservation Division of Akita Prefectural Government and Akita Prefectural Institute of Environmental Science for providing the actual data of water quality. Weather data was provided by Japan Meteorological Agency (JMA).

\section{References}

Inomata, Y. and Ogata, S. (1990): Supervised classification techniques using histogram overlay method and its application to an investigation on the turbidity around Kanmon Channel. J. Remote Sensing Society of Japan, 10-3, 39-53.

Ishibuchi, H. (1992): Fuzzy regression analysis.
J. Japan Soc. Fuzzy Theory and Systems, 4, $52-60$.

Miyazaki, K., Takano, H. and Yasuoka, Y. (1991): Satellite mapping of water quality in the Lake Kojima and its surrounding water area by Landsat data. J. Remote Sensing Soc. Japan, 11-2, 191-193.

Mizumoto, M. (1992): Fuzzy reasoning (1). J. Japan Soc. Fuzzy Theory and Systems, 4, $256-264$

Nishida, M. and Otsuka, K. (1995): Application of fuzzy regression model on water quality analysis with satellite image data and drawing of estimation map. Trans. IEE Japan, 115-C, 381-388.

Nishida, M., Otsuka, K. and Tabata, R. (1995): Fuzzy regression analysis of water quality with satellite remote sensing. Int. J. Soc. Mat. Eng. for Resources, 3, 178-186.

Oki, K. and Yasuoka, Y. (1997): Estimation of annual total nitrogen load in lake basin with remote sensing-Case study at Lake Kasumig aura-. J. Remote Sensing Soc. Japan, 17-1, $22-35$

Onishi, K., Hayashi, K., Toyama, H. and Ninomiya, H. (1986): Flow analysis due to personal computer. Asakura Press, 237p.

Tanaka, S., Hiki, S. and Konishi, H. (1990): Dispersion of microcystis and drift current in Lake Kasumigaura seen on Landsat image. $J$. Remote Sensing Society of Japan, 10-3, 25-35.

Yokoyama, R. (1983): Water quality detection by remote sensing. J. Computer Science of Japan, 24, 633-640.

(Received 14 December, 1998; Accepted 19 July, 1999) 


\section{リモートセンシングデータと数値モデルを \\ 用いた水質分布解析}

景山陽一*西田畺*

近年, 地球環境保護の見地から湖沼扩よび河川 における水質污濁状況のモニタリングの必要性が 高まり，広域性に優れた特徵を有するリモート七 ンシングデータの水質分布解析への利用が期待さ れている。しかしながら, ランドサット衛星の Thematic Mapper（TM）センサなどいった光学 センサにより取得されるリモートセンシングデー 夕は雲の影響を受けやすく, 利用可能な時系列デー 夕の取得は困難である場合が多い。さらに,リモー トセンシングデータのとらえる状況は瞬時情報で あるため, 水質状況をより適切に把握するために は水の流動を合わせて考慮する必要がある。

そこで本論文では秋田県の八郎湖を対象とし， 風により引き起こされる水の流れ，すなわち吹送 流が八郎湖における水質分布変化の最大要因と仮 定して検討を加えた。具体的には吹送流の数值モ
デルを作成してシミュレーションを行い，水質分 布図との対応について検討を加えた。なお，本論 文では種々のあいまいさを考慮するため, リモー トセンシングデータをファジィ数と見なした。す なわち, 測定された少数の水質デー夕を有効に活 用するため, 水質データとリモートセンシングデー 夕に関するファジィ回帰モデルを作成し，解析を 行った。さらに，得られた解に対してファジィレ ベルスライス処理を施し，水質分布図を作成した。

得られた結果について比較検討を行ったところ， 吹送流のシミュレーション結果と水質分布図との 間には関連性が認められた。また, 八郎湖は風に よる湖水の移動が主であり, 污濁物質の溜まりや すい場所の流動が少ないこと, 流れの淀む地点に おける水質污濁の著しいことなどが明らかとなっ た。

キーワード : 水質, 吹送流, 水質分布図, リモートセンシングデータ

${ }^{*}$ 秋田大学工学資源学部情報工学科 